\title{
実行機能困難度自己評価尺度の作成と信頼性・妥当性の検討
}

\author{
$\bigcirc$ 生田雄祐 ${ }^{1} \cdot$ 本村有理 ${ }^{1} \cdot$ 松田修 ${ }^{2}$ \\ ( ${ }^{1}$ 東京学芸大学大学院教育学研究科 $\cdot{ }^{2}$ 東京学芸大学教育心理学講座 $)$ \\ キーワード : 実行機能・遂行機能・自己評価尺度
}

\begin{abstract}
Development of the Self-rating Scale of Difficulties in Executive Functions and Examination of the Reliability and the Validity
Yusuke IKUTA $^{1}$, Yuri MOTOMURA ${ }^{1}$ and Osamu MATSUDA ${ }^{2}$

( ${ }^{1}$ Graduate School of Education, Tokyo Gakugei Univ., ${ }^{2}$ Tokyo Gakugei Univ.)

Key Words: Executive Functions, Self-rating Scale
\end{abstract}

実行機能 (遂行機能と同義)は, 目的を持った一連の活動を 有効に成し遂げるために必要な機能であり, 自ら問題を設定 し, 計画を立て, 実際の行動を効果的に行う能力とされてい る。日常生活で何らかの問題に遭遇した際, それを解決して いくために動員される一連の複雑な認知・行動機能の総称で ある(Lezak, 1995)。

実行機能の障害は発達障害, 認知症, あるいは, 前頭葉に 機能に障害のある人々(臨床群)で起こりやすいと言われてお り, 教育や医療の現場において注目されている。一方, 実行 機能はこれらの障害のない一般の人々 (非臨床群)の日常生活 や適応に少なからず影響することが示唆されている。しかし ながら, 実行機能研究は, その概念や測定方法に関して未だ 議論の的となっており, 臨床群はもちろん, 非臨床群におけ る理論的発達はいまだ結論を得ていない。

そこで, 今回, 実行機能に関する包括的研究の一つとして, 非臨床群を対象に, 実行機能の困難度を自己評価する尺度を 作成し, その信頼性と妥当性の検討を行うことを目的とした。

\section{方 法}

研究対象 大学生, 大学院生 223 名 (男性 43 名/女性 180 名) 質問紙構成 フェイス項目として性別, 年齢を記入してもら った。実行機能についての質問項目は, APA (2013), Miyake et al. (2000), Lezak (1995), Wilson et al. (1996) の実行機能 理論を参考にして,「プランニング」 4 項目, 「意思決定」 3 項 目，「ワーキングメモリ」 4 項目，「エラーフィードバック」 3 項目, 「習慣無視/抑制」3 項目, 「思考の柔軟性」4 項目, 「効 果的行動」5 項目, 「活動意欲」 3 項目, 合計 29 項目で構成さ れ, 実行機能に関する日常生活行動の困難度を問う質問紙を 作成した。回答方法は 4 件法 (「1. まったく当てはまらない」 〜「4.よく当てはまる」)であった。

\section{結 果}

質問項目す心゙て (29 項目)において, 天井効果・フロア効果 は見られなかったため, 主因子法プロマックス回転による探 索的因子分析を行った。その結果, 26 項目 6 因子が採択され, それぞれの因子名と質問項目数は「転換 (セットの切替/認知 的柔軟性)」6 項目, 「更新 (ワーキングメモリ)」6 項目, 「意 思決定」3 項目, 「活動意欲 (アパシー)」4 項目, 「プランニン
グ」4 項目「モニタリング(監視・自己管理)」3 項目とした。 尺度の各因子の因子間相関は表 1 のとおりである。

\section{表1 実行機能困難度自己評価尺度の因子間相関}

\begin{tabular}{ll|cccccc}
\hline & & I & II & III & IV & V & VI \\
\hline I & 転換 & - & .670 & .402 & .468 & .489 & .290 \\
III & 更新 & & - & .394 & .406 & .593 & .404 \\
IIII & 意思決定 & & & - & .368 & .429 & .237 \\
IV 活動意欲 & & & & - & .474 & .414 \\
V プランニング & & & & & - & .412 \\
VI モニタリング & & & & & & - \\
\hline
\end{tabular}

尺度の信頼性は, 各因子で $\alpha=.615 \sim .840$, 尺度全項目で $\alpha$ $=.914$ の值が確認された。そして尺度の確認的因子分析の結 果, 以下の適合度指標が得られた $\left(\mathrm{df}=281, \chi^{2}=581.776\right.$,

$\mathrm{GFI}=.838, \mathrm{AGFI}=.800, \mathrm{CFI}=.882, \mathrm{RMSEA}=.069)$ 。尺度の各 因子 (実行機能の構成要素) も先行研究と一致し, 尺度の構成 概念妥当性が概ね確認されたと考えた。

\section{考 察}

「実行機能困難度自己評価尺度」（全 26 項目）を作成し, 内 的整合性・構成概念妥当性を概小確認した。しかし, 今後も 尺度の質問項目精選, 因子構造モデルを追究する必要がある。

\section{謝 辞}

本研究は第一筆者が平成 26 年度に東京学芸大学教育心理 学講座へ提出した卒業研究を改稿したものであり, JSPS 科研 費 26380919 (研究代表者:松田修) の助成を受けたものである。 また本研究における尺度作成・データ収集に際して協力して いただいた, 武石捷さん, 堀仁憲さん, 市川幸子さん, 堀田 ゆかりさん, 松谷由美さん, そして研究に参加していただい た多くの方々に心より御礼申し上げます。

\section{引用文献}

American Psychiatric Association (2013). DIAGNOSTIC AND STATISTICAL MANUAL OF MENTAL DISORDERS FIFTH EDITION DSM-5 ${ }^{\mathrm{TM}}$. Washington, D.C., London, England: American Psychiatric Publishing.

Lezak M.D. (1995). Executive function and motor performance. Neuro Psychological Assessment. 3rd ed. Oxford : Oxford University Press pp.650-685.

Miyake, A., Friedman, N. P., Emerson, M. J., Witzki, A. H., Howerter, A., \& Wager, T. D. (2000). The unity and diversity of executive functions and their contribution to complex "frontal lobe" tasks: A latent variable analysis. Cognitive Psychology, 41, 49-100.

Wilson, B. A., Alderman, N., Burgess, P. W., Emslie, H., \& Evans,J. J. (1996). Behavioural Assessment of the Dysexecutive Syndrome. England: Thames Valley Test Company. 